\title{
Effect of Non-genetic Factors on Production Traits of Phule Triveni Cattle
}

\author{
Swapnali Uttamrao Rokade*, Dilip Kundalik Deokar, Ghoshita Suryakant Hingonekar \\ and Harshavardhan Shahaji Sonawane
}
Department of Animal Husbandry and Dairy Science, College of Agriculture Dhule, Mahatma Phule Krishi Vidyapeeth, Rahuri, India

*Corresponding author

\section{A B S T R A C T}

\begin{tabular}{|c|c|}
\hline $\begin{array}{l}\text { Ke y w o r d s } \\
\text { Phule Triveni, } \\
\text { TMY, LL, DP, } \\
\text { PMY }\end{array}$ & $\begin{array}{l}\text { The data on production performance of Phule Triveni cattle maintained at Research cum } \\
\text { Development Project on Cattle (RCDP), Mahatma Phule Krishi Vidyapeeth, Rahuri } \\
\text { district, Ahmednagar, (M.S) were utilized for present study. The data were analyzed by } \\
\text { considering the effects of period of calving, season of calving and lactation order as non- } \\
\text { genetic factors. The least squares means recorded for total milk yield (kg), lactation length }\end{array}$ \\
\hline Artic & \\
\hline $\begin{array}{l}\text { Accepted: } \\
\text { 04 December } 2020 \\
\text { Available Online: } \\
\text { 10 January } 2021\end{array}$ & $\begin{array}{l}\text { on traits TMY,LL }(\mathrm{P}<0.05) \text { and PMY }(\mathrm{P}<0.01) \text { while it was non-significant on DP. The } \\
\text { effect of season of calving was non-significant on all the traits viz TMY, LL, DP and } \\
\text { PMY. The effect of order of lactation was significant on trait PMY }(\mathrm{P}<0.01) \text {, while it was } \\
\text { non-significant on traits TMY, LL, DP. }\end{array}$ \\
\hline
\end{tabular}

\section{Introduction}

Increased pressure for intensified milk production and simultaneous rise in environmental temperature due to global warming has increased the thermal load on dairy animals. Elevated environmental temperature combined with high humidity causes discomfort and escalates the stress level in animals which is reflected in terms of reduced physiological and metabolic activities that results in reduced growth, drop in production and reproduction in farm animals. Heat stress is one of the most vital environmental stressor that has negative impact on milk yield, milk composition (fat $\%$, SNF\%, protein \% etc.). Construction of Temperature Humidity Index (THI) by combining several climatological parameters like dry bulb, wet bulb temperature along with relative humidity to quantify the thermal stress is one of the best methods to assess heat stress on animals. Several research workers have reported that there exists a threshold THI value, above which the negative effects of heat stress is observed on animals. Mitigation strategies to combat heat stress includes selection of heat tolerant animals and their breeding, inclusion of heat tolerance as a trait while constructing selection index, providing 
balanced nutrition to the animals and implementation of good ventilation along with suitable cooling system in the farm (Behera et al., 2020). The temperature and humidity are changes day to day and even seasonal as well as periodical. The literature on Phule Triveni crossbred cattle on this aspect is scanty. Therefore, present investigation was undertaken.

\section{Materials and Methods}

The data of Phule Triveni cows maintained at Research Cum-Development Project on Cattle, M.P.K.V., Rahuri for a period from 2009 to 2019 (10 years) were collected for present investigation for various production traits viz., Total lactation milk yield (kg),Lactation length (days),Dry period (days) and Peak milk yield $(\mathrm{kg})$.To examine the production traits, the research data was classified into 3 periods of calving viz. $\mathrm{P}_{1}$ (2009-2011), $\mathrm{P}_{2}$ (2012-2014), $\mathrm{P}_{3}$ (2015above); 3 seasons of calving, viz. $S_{1}$ (Rainy) June- September, $\mathrm{S}_{2}$ (Winter) OctoberJanuary and $\mathrm{S}_{3}$ (Summer) February-May; 5 order of lactation viz. $\mathrm{L}_{1}$ first lactation, $\mathrm{L}_{2}$ second lactation, $\mathrm{L}_{3}$ third lactation, $\mathrm{L}_{4}$ fourth lactation, $\mathrm{L}_{5}$ fifth lactation. The effects of nongenetic factors like period of calving, season of calving and parity were estimated by using least-square analysis as suggested by Harvey (1990). The model was used with the assumption that different components being fitted into the model were as linear, independent and additive. The model used was as follows:

$Y_{i j k l}=\mu+A_{i}+B_{j}+C_{k}+e_{i j k l}$

where $Y_{i j k l}$, observation of $1^{\text {th }}$ animal, $k^{\text {th }}$ parity, $\mathrm{j}^{\text {th }}$ season of calving, $\mathrm{i}^{\text {th }}$ period of calving; $\mu$ overall mean, $A_{i}$ fixed effect of $i^{\text {th }}$ period of calving ( 1 to 3 ), $B_{j}$ fixed effect of $j^{\text {th }}$ season of calving (1 to 3 ), $\mathrm{C}_{\mathrm{k}}$ fixed effect of $\mathrm{k}^{\text {th }}$ parity (1 to 5); $\mathrm{e}_{\mathrm{ijkl}}$ random error $\sim$ NID $(0$, $\left.\sigma^{2} e\right)$.
Whenever the effects were significant Duncan's Multiple Range Test as modified by Kramer (1957) was used to make pair wise comparison among the least square means with the use of inverse elements and root mean squares for error.

If the values

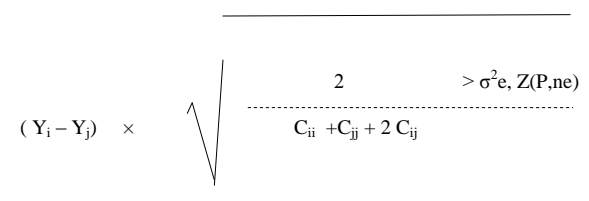

Where,

$Y_{i}-Y_{j}$ : Difference between two least squares means

$\mathrm{C}_{\mathrm{ii}}$ : Corresponding $\mathrm{i}^{\text {th }}$ diagonal elements of $\mathrm{C}$ matrix

$\mathrm{C}_{\mathrm{jj}}$ : Corresponding $\mathrm{j}^{\text {th }}$ diagonal elements of $\mathrm{C}$ matrix

$\mathrm{Z}$ (P, ne): Standardized range value in Duncan's table at the chosen level of probability for the error degrees of freedom

P: Number of means involved in the comparison

$\sigma^{2} \mathrm{e}:$ Root mean squares for error

\section{Results and Discussion}

The least squares means recorded for total milk yield (kg), lactation length (days), dry period (days) and peak milk yield $(\mathrm{kg})$ were presented in Table 1.

\section{Total milk yield (kg)}

The overall least squares mean of total milk yield in Phule Triveni cow was 2612.88 \pm $75.48 \mathrm{~kg}$. This was in accordance with Deokar 
(2003) in Gircrossberd cows. Whereas, higher values were reported by Ambhore et al., (2017) in Phule Triveni $(2855 \pm 43 \mathrm{~kg})$, Raut et al., (2017) in $\mathrm{HF} \times$ Girhalfbreds $(2556.82$ $\mathrm{kg}$ ), Jadhav et al., (2019) in HF $\times$ Girhalfbreds $(2701.77 \pm 46.04 \mathrm{~kg})$, Gaikwad et al., (2018) in HF $\times$ Girhalfbreds (2703.10 \pm $97.91 \mathrm{~kg}$ Patond (2013) in FJG cattle. However, lower total milk yield was noticed by Hadge et al., (2012) in Jersey x Sahiwal, Arya et al., (2013) in crossbred cows and Thombare et al., (2013) in HF $\times$ Deoni cows.

The influence of period of calving on total milk yield was highly significant $(\mathrm{P}<0.01)$ in Phule Triveni cow. This was in accordance with Pandey et al., (2018) in Sahiwal cattle and Baranwal et al., (2018) in Vrindavani cows. In Phule Triveni cow, total milk yield $(\mathrm{kg})$ of cows calved during period $\mathrm{P}_{1}(3158.27$ $\pm 114.36 \mathrm{~kg})$ was significantly highest followed by cows calved in $\mathrm{P}_{3}$ (2345.95 \pm $154.29 \mathrm{~kg})$ and $\mathrm{P}_{2}(2740.98 \pm 98.50 \mathrm{~kg})$ which were at par with each other.

The influence of season of calving on total milk yield was non-significant in Phule Triveni cow. The present results were in agreement with Hadge et al., (2012) in Sahiwal and Jersey $\mathrm{x}$ Sahiwal crossbreds, Patond (2013) in Gir triple crossbred cows, Bhutkar et al., (2014) in Deoni cows, Radhika et al., (2012) in crossbred cows and Pandey et al., (2018) in Sahiwal cattle. In present study Phule Triveni cows calved during winter season yielded highest TMY (2724.42 \pm $123.75 \mathrm{~kg})$ followed by rainy season $(2559.36$ $\pm 129.35 \mathrm{~kg}$ ) and lowest TMY in summer season $(2554.85 \pm 124.06 \mathrm{~kg})$.

The variation due to order of lactation in total milk yield $(\mathrm{kg})$ of Phule Triveni cow was non-significant. Similar results were obtained by Radhika et al., (2012) in crossbred cows. However contradictory results were obtained by Deokar et al., (2003) in FG, JG,FJG, JFG,
BFG, Kale et al., (2001a) in FJG, JFG, BFG, Pol et al., (2015) and Garudkar et al., (2015) in Phule Triveni, Jadhav et al., (2010) in HF × Girhalfbreds. In Phule Triveni cow, the differences in total milk yield of cows $\mathrm{L}_{3}$ $(2828.24 \pm 155.76 \mathrm{~kg}), \mathrm{L}_{5}(2723.65 \pm 203.83$ $\mathrm{kg}), \mathrm{L}_{2}(2639.39 \pm 143.06 \mathrm{~kg})$ and $\mathrm{L}_{4}(2613.98 \pm$ $173.10 \mathrm{~kg}$ ) were at par with each other and significantly higher than and $\mathrm{L}_{1}(2259.24 \pm$ $139.64 \mathrm{~kg}$ ). The $\mathrm{L}_{3}$ and $\mathrm{L}_{5}, \mathrm{~L}_{2}$ and $\mathrm{L}_{4}$ which was at par with each other and $\mathrm{L}_{3}$ was significantly higher than those $\mathrm{L}_{1}$. The difference in TMY among total cows calved during $\mathrm{L}_{3}$ and $\mathrm{L}_{5}, \mathrm{~L}_{2}$ and $\mathrm{L}_{4}$ were at par to each other.

\section{Lactation length}

The overall least squares mean of lactation length in Phule Triveni cow was $306.43 \pm$ 5.51 days which was in close agreement with Pol et al.,(2013) in Phule Triveni cows. Whereas, higher lactation length were reported by Usman et al., (2012) in HF cows, Patond (2013) in Gir triple cross cows, Ambhore et al., (2017) in Phule Triveni cows (331.3 \pm 3 days), Jadhav et al., (2019) in HF $\times$ Girhalfbreds $(320.43 \pm 3.04$ days $)$, Mote $e t$ al., (2019) in IFG (352.21 \pm 5.14 days) FG (327.22 \pm 4.15 days), FIG (331.71 \pm 3.97 days), IFJG (358.33 \pm 3.81 days), $R$ (343.37 \pm 7.52 days), Gaikwad et al., (2018) in HF $\times$ Girhalfbreds (332.80 \pm 8.72 days). However, lower lactation length was observed by Hadge et al., (2012) in Jersey $\times$ Sahiwal, Thombare et al., (2013) in $\mathrm{HF} \times$ Deonicows.

The variation due to period of calving in lactation length was significant $(\mathrm{P}<0.05)$ in Phule Triveni cows. The significant effect of period of calving on lactation length was reported by Ambhore et al., (2017) in Phule Triveni cows, Mote et al., (2019) in IFG, IFJG and Patond (2013) in Gir triple cross cows. However, non significant effect of period of calving on lactation length was also 
noticed by Jadhav et al., (2019) in HF $\times$ Girhalfbreds, Mote et al., (2019) in FG, FIG, R, Gaikwad et al., (2018) in HF $\times$ Girhalfbreds, Patond (2009) in Jersey cows, Hadge et al., (2012) in Jersey $\times$ Sahiwalhalfbreds. In Phule Triveni, lactation length (days) was highest in cows calved during period $\mathrm{P}_{3}(316.73 \pm 11.27)$ followed by $\mathrm{P}_{1}(316.11 \pm 8.35)$ and lowest in $\mathrm{P}_{2}(286.45 \pm$ 8.21). The differences obtained among the cows calved during $\mathrm{P}_{3}$ and $\mathrm{P}_{2}$ were at par to each other.

The influence of season of calving on lactation length was non-significant in Phule Triveni cows. These results were in accordance with Ambhore et al., (2017) in Phule Triveni cows, Mote et al., (2019) in IFG, FG, FIG, R, Jadhav (2011) in HG halfbreds, Hadge et al., (2012) in Jersey $\times$ Sahiwalhalfbreds, Patond (2013) in Gir triple cross cows and Bhutkaret al., (2014) in Deoni cows. However, present results did not agreed with Jadhav (2019) in HF $\times$ Girhalfbreds, Thombare et al., (2013) in HF $\times$ Deonihalfbreds and Patond (2014) in Gir triple cross cows, Kamble et al., (2016) in Phule Triveni cows, Mote et al., (2019) in IFJG. InPhule Triveni cows, the highest lactation length was observed in cows calved during winter (316.49 \pm 9.04days) season followed by rainy (306.74 \pm 9.45 days) and lowest in summer $(296.07 \pm 9.06$ days $)$ season.

The effect of order of lactation on lactation length was non-significant in Phule Triveni cows. These results were in accordance with Garudkar et al., (2015) in Phule Triveni cows, Patond (2013) in Gir triple cross and Thombare et al., (2013) in HF $\times$ Deoni crossbred cows. However, significant effect of order of lactation on lactation length was observed by Kamble (2003) in Gir crossbred cows and Mhasade (2010) and Jadhav (2011) in FG halfbreds. In Phule Triveni cows, the highest lactation length was observed in $\mathrm{L}_{2}$
(320.87 \pm 10.45 days) lactation followed by $\mathrm{L}_{1}(320.75 \pm 10.20$ days $), \mathrm{L}_{3}$ (308.88 \pm 11.38 days $), \mathrm{L}_{4}(291.25 \pm 12.65$ days $)$ and lowest in $\mathrm{L}_{5}$ (290.40 \pm 14.89 days) lactation. In HF X Gir no specific trend of lactation length was noticed during different lactations.

\section{Dry Period}

The overall mean dry period recorded in Phule Triveni was $144.12 \pm 11.38$ days. These results were in close agreement with Roy et al., (1993) in FT cows. Whereas, higher values were observed by Pandey et al., (2009) in FJH, Usman et al., (2012) in HF cows, Hadgeet al., (2012) in Jersey $\times$ Sahiwal cows and Hassan et al., (2013) in crossbred cows. However, lower values were noticed by Kamble (2003) in HG cows, Deokar et al., (2008) in Phule Triveni cows(93.57 \pm 4.94 days), Zol et al., (2009) in Phule Triveni cows(79.06 \pm 1.89 days), Kamble et al., (2016) in Phule Triveni cows(114.74 \pm 7.54 days), Ambhore et al., (2017) in Phule Triveni cows (93 \pm 3 days), Jadhav et al., (2019) in HF $\times$ Girhalfbreds(88.40 \pm 2.58 days), Gaikwad et al., (2018) in HF $\times$ Girhalfbreds (85.59 \pm 7.45 days).

The variation due to period of calving in dry period was non-significant in Phule Triveni. Similar results were observed by Kamble (2003) in FG, FJG, JFG and BFG crossbreds, Deokar et al., (2008) in Phule Triveni cows, Pandey et al., (2009) in FJH crossbreds and Usman et al., (2012) in HF cows, Jadhav et al., (2019) in HF $\times$ Girhalfbreds, Gaikwad et al., (2018) in HF $\times$ Girhalfbreds. In Phule Triveni, the dry period (days) was largest in cows calved during period $\mathrm{P}_{2}(148.10 \pm 16.95)$ followed by $\mathrm{P}_{3}(144.65 \pm 23.27)$ and lowest in $P_{1}(139.62 \pm 17.25)$. The results revealed that the dry period linearly increased in cows calved during period $\mathrm{P}_{2}$ and slightly decreased during $\mathrm{P}_{3}$ in Phule Triveni cows. 
Table.1 Least squares means for total milk yield (kg), lactation length, dry period, peak milk yield as affected by non-genetic factors

\begin{tabular}{|c|c|c|c|c|c|}
\hline \multirow[t]{2}{*}{ Effect } & \multirow[t]{2}{*}{$\mathbf{N}$} & \multicolumn{4}{|c|}{ LEAST SQUARE MEANS } \\
\hline & & Total Milk Yield & Lactation Length & Dry period & Peak milk yield \\
\hline$\mu$ & 137 & $2612.88 \pm 75.48$ & $306.43 \pm 5.51$ & $144.12 \pm 11.38$ & $14.87 \pm 0.30$ \\
\hline \multicolumn{6}{|c|}{ Period of calving } \\
\hline $\mathbf{P}_{1}$ & 53 & $3158.27^{\mathrm{a}} \pm 114.36$ & $316.11^{\mathrm{ab}} \pm 8.35$ & $139.62 \pm 17.25$ & $16.66^{\mathrm{a}} \pm 0.45$ \\
\hline $\mathbf{P}_{2}$ & 55 & $2334.42^{\mathrm{c}} \pm 112.40$ & $286.45^{\mathrm{b}} \pm 8.21$ & $148.10 \pm 16.95$ & $14.62^{\mathrm{ab}} \pm 0.45$ \\
\hline $\mathbf{P}_{3}$ & 29 & $2345.95^{b} \pm 154.29$ & $316.73^{\mathrm{a}} \pm 11.27$ & $144.65 \pm 23.27$ & $13.32^{b} \pm 0.61$ \\
\hline \multicolumn{6}{|c|}{ Season of calving } \\
\hline $\mathbf{S}_{\mathbf{1}}$ & 44 & $2559.36 \pm 129.35$ & $306.74 \pm 9.45$ & $147.98 \pm 19.51$ & $14.58 \pm 0.51$ \\
\hline $\mathbf{S}_{\mathbf{2}}$ & 46 & $2724.42 \pm 123.75$ & $316.49 \pm 9.04$ & $126.02 \pm 18.66$ & $14.57 \pm 0.49$ \\
\hline $\mathbf{S}_{\mathbf{3}}$ & 47 & $2554.85 \pm 124.06$ & $296.07 \pm 9.06$ & $158.37 \pm 18.71$ & $15.44 \pm 0.49$ \\
\hline \multicolumn{6}{|c|}{ Order of lactation } \\
\hline $\mathbf{L}_{1}$ & 35 & $2259.24 \pm 139.64$ & $320.75 \pm 10.20$ & $147.39 \pm 21.06$ & $11.60^{c} \pm 0.56$ \\
\hline $\mathbf{L}_{2}$ & 33 & $2639.89 \pm 143.06$ & $320.87 \pm 10.45$ & $126.93 \pm 21.57$ & $14.77^{b c} \pm 0.56$ \\
\hline $\mathbf{L}_{\mathbf{3}}$ & 30 & $2828.24 \pm 155.76$ & $308.88 \pm 11.38$ & $132.05 \pm 23.49$ & $15.85^{\mathrm{b}} \pm 0.62$ \\
\hline $\mathbf{L}_{4}$ & 23 & $2613.98 \pm 173.10$ & $291.25 \pm 12.65$ & $163.24 \pm 26.11$ & $16.09^{\mathrm{a}} \pm 0.68$ \\
\hline $\mathbf{L}_{5}$ & 16 & $2723.05 \pm 203.83$ & $290.40 \pm 14.89$ & $151.01 \pm 30.74$ & $16.02^{\mathrm{ab}} \pm 0.81$ \\
\hline
\end{tabular}


The variation due to season of calving in dry period was non-significant in Phule Triveni. These results were in agreement with Deokar et al., (2008), Zol et al., (2009), Kamble et al., (2016) and Ambhore et al., (2017) in Phule Triveni cows, Jadhav et al., (2019) in HF $\times$ Girhalfbreds, Kamble (2003) in HG halfbreds, Zol (2007) in Phule Triveni, Pandey et al., (2009) in FJH crossbreds, Shinde (2010) in HF and Hadge et al., (2012) in Jersey $\times$ Sahiwal crossbred cows and Bhutkar et al., (2014) in Deoni cows. In Phule Triveni, the longest dry period was observed

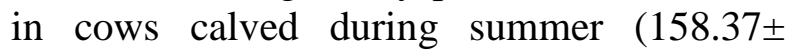
18.71 days) season followed by rainy (147.98 \pm 19.51days) and shortest in those calved in winter(126.02 \pm 18.66 days) season.

The difference due to order of lactation in dry period was non-significant in Phule Triveni cows. These results were similar to Zolet al., (2009) in Phule Triveni cows, Kamble (2003) in Gir crossbreds, Zol (2007) in Phule Triveni, Shelar (2012) in Gir crossbreds. In Phule Triveni cows, the longest dry period (days) was observed in cows during $\mathrm{L}_{4}$ (163.24 \pm 26.11) followed by $\mathrm{L}_{5}$ (151.01 $\pm 30.74), \mathrm{L}_{1}(147.39 \pm 21.06), \mathrm{L}_{3}(132.05 \pm$ 23.49) and lowest in $L_{2}(126.93 \pm 21.57)$ lactation. In Phule Triveni cows in the present study no specific trend of dry period was noticed for different lactations.

\section{Peak Milk Yield}

The overall least squares mean observed for PMY was $14.87 \pm 0.30 \mathrm{~kg}$ in Phule Triveni cattle which was in close agreement with Patond (2009) reported in Jersey cows, Shelke (2012) in Phule Triveni, whereas, higher values were observed by Patond (2013) in Gir triple cross cows. However, lower values were noticed by Kale et al., (2001) in FJG $(14.87 \pm 0.13 \mathrm{~kg}) \mathrm{JFG}(14.57 \pm 0.25 \mathrm{~kg})$ and BFG (14.91 $\pm 0.19 \mathrm{~kg})$, Kamble (2003) in HG cows.
The variation due to period of calving in PMY was significant $(\mathrm{P}<0.01)$ in Phule Triveni which was also noticed by Kale et al., (2001) in FJG (14.87 $\pm 0.13 \mathrm{~kg}) \mathrm{JFG}$ (14.57 \pm $0.25 \mathrm{~kg})$ and BFG (14.91 $\pm 0.19 \mathrm{~kg})$, Patond et al., (2009) in Jersey cows, Bhutkaret al., (2014) in Deonicattle. The PMY (kg) of cows calved during period $P_{1}(16.66 \pm 0.45)$ is higher than $\mathrm{P}_{3}(13.32 \pm 0.61)$ and at par with those calved during $\mathrm{P}_{2}(14.62 \pm 0.45)$. The differences in PMY among cows calved during $\mathrm{P}_{1}$ and $\mathrm{P}_{2}$ and between $\mathrm{P}_{2}$ and $\mathrm{P}_{3}$ were at par with each other. The results revealed that the PMY linearly decreased in cows calved during period $\mathrm{P}_{1}$ to $\mathrm{P}_{3}$ in Phule Triveni.

The variation due to season of calving in PMY was non-significant in Phule Triveni. These results were in agreement with Nanavati and Singh et al., (2004) reported in Gir cattle, Patond et al., (2009) in Jersey cows, Shelke et al., (2012) in Phule Triveni cows Bhutkar et al., (2014) in Deoni cattle and Radhika et al., (2012) in crossbred cows. However significant results were obtained by Kale et al., (2001) in FJG, JFG and BFG. In Phule Triveni, the highest PMY was observed in cows calved during summer (15.44 \pm 0.49 $\mathrm{Kg}$ ) season and lowest in winter (14.57 \pm $0.49 \mathrm{Kg})$.

The difference in PMY due to order of lactation was significant in Phule Triveni $(\mathrm{P}<0.01)$. Similar results were noticed by Kale et al., (2001) in FJG $(14.87 \pm 0.13 \mathrm{~kg})$ JFG $(14.57 \pm 0.25 \mathrm{~kg})$ and BFG (14.91 \pm 0.19 $\mathrm{kg}$ ) and Patond (2013) in Gir triple cross cows. The PMY (kg) of cows calved during order of lactation $\mathrm{L}_{4}(16.09 \pm 0.68)$ is significantly higher than $\mathrm{L}_{3}(15.85 \pm 0.62)$, $\mathrm{L}_{2}(14.770 \pm 0.56)$ and $\mathrm{L}_{1}(11.60 \pm 0.56)$ and at par with those calved during $\mathrm{L}_{5}(16.02 \pm 0$. 81). The differences in PMY among cows calved during $\mathrm{L}_{4}$ and $\mathrm{L}_{5}$, between $\mathrm{L}_{3}$ and $\mathrm{L}_{5}$ and $\mathrm{L}_{2}$ were at par with each other. 
In Phule Triveni, the highest PMY (kg) was observed during $\mathrm{L}_{4}(16.09 \pm 0.68)$ followed by, $\mathrm{L}_{5}(16.02 \pm 0.81), \mathrm{L}_{3}(15.85 \pm 0.0 .62)$, $\mathrm{L}_{2}(14.77 \pm 0.56)$ and lowest in $\mathrm{L}_{1}(11.60 \pm$ $0.56)$ lactation. In the present investigation no specific trend of PMY was noticed for different lactations. The differences among the cows calved during $\mathrm{L}_{4}$ and $\mathrm{L}_{1}, \mathrm{~L}_{5}$ and $\mathrm{L}_{1}$, $\mathrm{L}_{3}$ and $\mathrm{L}_{1}$ as well as $\mathrm{L}_{2}$ and $\mathrm{L}_{1}$ are at par to each other. The significantly lowest PMY was recorded in cows during $\mathrm{L}_{1}$ lactation.

\section{References}

Ambhore, G.S., Avtar Singh, Deokar, D.K., Gupta, A.K., Manvendra, Singh and VedPrakash. (2017). First lactation production and reproduction performance of Phule Triveni cattle in hot arid region of Maharashtra, Indian. J.Anim.Sci. 87(1): 105-108.

Arya, V.K. and Tailor, S.P. (2013).Factors affecting production and reproduction traits of Gir and crossbred cattle. Journal Progressive Agriculture. 4(1): 135-138.

Baranwal A., Neerasa G. S., Pruthviraj D.R., BabuLalSaini, SatishKumar and Avneesh Kumar. (2018). Effect of Environmental Factors on Production and Reproduction Traits of Vrindavani Cattle. International Journal of Livestock Research, eISSN: 2277-1964, 8 (06):113-122.

Behera R.,Mandal A.,Rai S., Karunakaran M. and Mondal M. (2020). Temperature Humidity Index and its relationship with production traits of dairy cattle and buffaloes - Review. International Journal of Livestock Research 10(3): 38-48.

Bhutkar S.S., Thombre B. M. and Bainwad D.V. (2014). Effect of non-genetic factors on production traits in Deoni Cows IOSR Journal of Agriculture and Veterinary Science, 7(12) 2319-2380.

Deokar, D.K., Pachpute, S.T., Kale, S.V. and Naikare, B.D. (2003). Studies on fat corrected milk yield in two and three breed Gir crosses. J. Maharashtra Agric. Univ. 28(1): 72-74.

Deokar, D.K. (2003). System analysis for optimization of production in crossbred cattle. Ph. D. Thesis submitted to M.P.K.V., Rahuri.

Gaikwad, U.S., Deokar, D.K. and Bhoite, U.K. (2018). Studies on first lactation production traits of $\mathrm{Hf} \times$ Girhalfbreds. $J$. Anim. Vet. Sci. 5(2):12-15.

Garudkar, S. R., Patond, M.N. and Deokar D.K. (2015). Effect on non-genetic factors on some productive traits in Phule Triveni cows. Indian J.Vet.Res. 24(1): 23-26.

Hadge, M.R., Kuralkar, S.V., Ali, S.Z., Kharkar, K.P. and Sawaimul, A.D. (2012). Genetic studies on productive traits of Sahiwal and Jersey $\mathrm{x}$ Sahiwal crossbred cows. Indian J. Anim. Res. 46(1): 92-94.

Harvey W.R. (1990). Least-squares analysis of data with unequal subclass numbers. ARS H-4, U.S.D.A, Washington.

Jadhav, S.S., Deshmkh, A.R., Deokar, D.K. and Fulpagare, Y.G., (2010). Effect of non genetic factors on production traits of Girhalfbreds. Asian J. Anim. Sci. 5(1): 2324.

Jadhav, P.D. (2011). Generation wise comparative reproduction and production performance of HF x Gir and Phule Triveni synthetic cows. M.Sc (Agri.) Thesis submitted to M.P.K.V., Rahuri.

Jadhav, S.S., Deokar, D.K., Fulpagare, Y.G., Bhoite, U.V., Mandakmale, S.D. and Nimbalkar, C.A. (2019). Effects of genetic and non-genetic factors on first lactation production and reproduction traits in HF x Gir cattle. Int. J. Curr. Microbio. App. Sci. 8(1): 45-51.

Kale, D.D., Ulmel B.R., Deokar, D.K. and Pachpute, S.T. (2001). Genetic studies on peak milk yield in Triple crossbred cows. J. Maharashtra Agric. Univ. 26(2): 216218.

Kamble, S.S. (2003). Effect of different types of calving on reproductive and productive performance of crossbred cattle. M.Sc. (Agri.) Thesis submitted to M.P.K.V., Rahuri.

Kamble V.P., Deokr D.K. and Bhoite U.Y. (2016). Studies on first lactation production traits of Phule Triveni. J.Agric.Res.Technol. 41(1):135-141.

Kramer, C.V. (1957). Extension of multiple range 
test to group correlated adjusted mean. Biometrics, 13: 13-20.

Mote, M.G., Nimbalkar, C.A., Deokar, D.K. and Gaikwad, U.S. (2019). Effect of genetic and non-genetic factors on first lactation production traits in crossbreds of Gir with Holstein friesion and Jersey cattle breeds. Agric.Ress.:1-5.

Mhasade, B.S. (2010). Effect of age and weight at first calving on production performance of HF x Gir crossbreds. M.Sc.(Agri.) Thesis submitted to M.P.K.V., Rahuri.

Nanavati, S. and Singh, A. (2004).Non-genetic factors affecting production traits in Gir cattle.Indian J. Dairy Sci. 57 (5): 342346.

Pandey, H.S., Suman, C.L. and Madhuri, S. B. (2009). Reproduction and production performance of three breed crosses in cattle. Indian J. Anim. Res. 43(1): 32-36.

Pandey M. and Raja K.N., Saleem Yousuf and Gupta A.K. (2018). Effect of non-genetic factors on first lactation 305 days and lifetime milk yield in Sahiwal cattle. Indian J Dairy Sci., 72(1): 89-92.

Patond, M.N. (2009). Persistency of milk yield in Jersey cattle. M.Sc. (Agri.) Thesis submitted to M.P.K.V., Rahuri.

Patond, M.N. (2013). Modelling of lactation curve in Gir triple cross cows. Ph. D. Thesis submitted to M.P.K.V., Rahuri.

Pol, K.E., Dhage, S.A., Pachpute, S.T. and Khutal, B.B. (2013). Generation wise production efficiency of Phule Triveni synthetic cow. J. Agric. Res. Technol. 38(1): 117-129.

Pol, K.E., Khutal, B.B., Deokar, D.K. and Deshmukh, A.R. (2015). Factors affecting lactation length and 305 days milk yield of Phule Triveni synthetic cows. Indian J.Vet.Res. 24(1): 23-26.
Radhika G., Ajithkumar S., Rani A., Sathian C.T., Anilkumar K., Usha A. P. and Dinesh C.N. (2012). Milk yield and composition of crossbred cows in the hilly Wayanad district of Kerala, India. Indian Journal of Animal Sciences 82 (10): 1251-1254.

Roy, P.K., Basu, S.B. and Pachlang, S.V. (1993).Association between milk production and reproduction traits in crossbred cows. Indian J. Dairy Sci. 45(6) 274-277.

Shelke, M.G. (2012). Generation wise persistency of milk production in Phule Triveni Synthetic cows M. Sc. (Agri.) Thesis submitted to M.P.K.V., Rahuri.

Shinde, A.S. (2010). Studies on breeding efficiency of HF halfbreds. M.Sc. (Agri.) Thesis submitted to M.P.K.V., Rahuri.

Shubha Lakshmi, B., Ramesh Gupta, B., Sudhakar, K., GnanaPrakash. and Lt. Col. Susheel Sharma. (2009). Genetic analysis of production performance of Holstein Friesian x Sahiwal cows. Tamilnadu J. Vet. Anim. Sci. 5(4): 143-148.

Thombare, B.M., Bainwad, D.V., Zewdu Wondifraw. (2013). Effect of non-genetic factors on milk production of Holstein Friesian x Deoni crossbred cows. Af. $J$. Dairy Farming Milk Prod. 1(4): 79-84.

Usman, T., Suhail, S. M., Ahmed, S., Qureshi, M. S. and Wang, Y. (2012). Performance traits study of Holstein Friesian cattle under subtropical conditions. J. Anim. Plant Sci. 22 (2):92-95.

Zol, S.R. (2007). Studies on generation wise breeding efficiency of Phule Triveni crossed cows at R.C.D.P organized farm. M.Sc.(Agri.) Thesis submitted to M.P.K.V., Rahuri.

\section{How to cite this article:}

Swapnali Uttamrao Rokade, Dilip Kundalik Deokar, Ghoshita Suryakant Hingonekar and Harshavardhan Shahaji Sonawane. 2021. Effect of Non-genetic Factors on Production Traits of Phule Triveni Cattle. Int.J.Curr.Microbiol.App.Sci. 10(01): 147-154. doi: https://doi.org/10.20546/ijcmas.2021.1001.017 